\title{
Professor Colvin Goonaratna - an academic professional with loads of talent
}

\section{Anuruddha M Abeygunasekera ${ }^{1}$}

For more than 25 years I have had the privilege and pleasure of enjoying a close friendship with Professor Colvin Goonaratna, a great medical teacher, skilled and inventive researcher, practical and efficient manager, and Sri Lanka's unrivalled medical editor and writer. I count our friendship, which commenced from my special interest in clinical research and writing, as one of the blessings of my life. We rejoice that he is still bristling with ideas for research and writing although he is now over 80 years. Doing justice to his life and work requires a lengthy essay. I trust that the editors would please oblige by publishing this article, for "The history of the world is but the biography of great men” as Thomas Carlyle has asserted.

Colvin Goonaratna (CG) was born in September 1937. His primary education was at a vernacular Temple School in Rawatawatta and Prince of Wales' College in

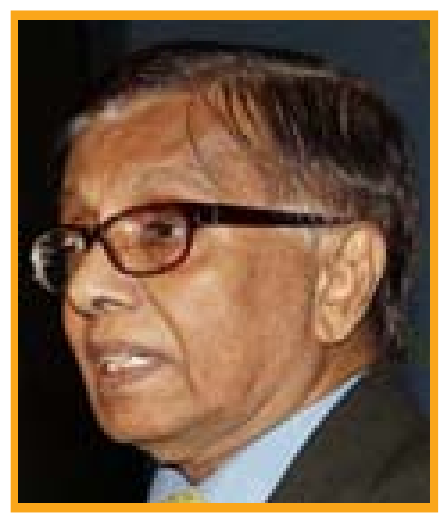
Moratuwa. His secondary education was at Royal College Colombo. CG entered the Faculty of Medicine of the University of Ceylon in 1957, and qualified MBBS in 1962, with Second Class Honours in the $2^{\text {nd }}, 3^{\text {rd }}$ and Final examinations. After his internship year at the General Hospital Colombo (now NHSL) he was transferred, with his consent, to the General Hospital Badulla as Senior House Officer to the Consultant Orthopaedic Surgeon, Dr. T. N. Shanmugalingam. Doctors were in short supply at that time, so within six months he was also appointed Acting Judicial Medical Officer for the Badulla District. This gave him the opportunity to travel widely in his second-hand Ford Prefect (2 Sri 8192) within the Uva Province for many open-air post-mortem examinations. Some of them were performed after walking long distances in bear and leopard infested jungles, accompanied by two police constables (of whom one carried a firearm), the coroner, and the man who does the dissections.

After three years at G H Badulla, he was transferred to the Leprosy Hospital, at Hendala. There he discovered a neglected stone inscription, overgrown with weeds, indicating the year (1708) in which the Leprosy Hospital first started to function during the period of Dutch Governor Hendrick Becker (1707-1716). This stimulated CG to publish two articles on the history of leprosy in Ceylon during the Dutch Period (1658-1791) in the British journal Medical History. As a consequence of a difference of opinion CG had with the Superintendant of the National Leprosy Campaign regarding the leprosy control programme, he was sent on a disciplinary transfer as D.M.O, District Hospital Kitulgala. After two years at Kitulgala he was selected to the Physiology Department of the Faculty of Medicine in Colombo as a Demonstrator, and within one year or so, appointed Probationary Lecturer, with Professor K.N. Seneviratne as Head of the Department.

In June 1970 Lord Rosenheim, Professor of Medicine at the University of London and University College Hospital Medical School (UCHMS), and President, Royal College of Physicians of London, came to Ceylon as primus inter pares from among 22 of the world's most distinguished medical luminaries invited as the Guests of Honour to the Centenary Celebrations of the Faculty of Medicine (1870-1970) of the University of Ceylon. CG had to be Lord Rosenheim's

Ceylon Medical Journal 2020; 65: 1-4

DOI: http://doi.org/10.4038/cmj.v65i1-2.9129

${ }^{1}$ Urological Surgeon, Colombo South Teaching Hospital, Sri Lanka.

Correspondence: AMA, e-mail: <amabey@sltnet.lk> 
"honorary chauffeur" in Colombo. On the evening of the last day of his visit, Lord Rosenheim told him that he had arranged a supervisor for his PhD at the request of Professor Seneviratne. The supervisor's name was Professor Oliver Wrong, the then Professor of Medicine of the Faculty of Medicine of the University of Dundee. CG joined Professor Wrong's Medical Unit in Dundee as a Clinical and Research Fellow in September 1970, and registered for a PhD in that University. Professor Wrong moved to the University of London as Professor of Medicine, and Head of the Medical Unit of the University College Hospital Medical School (UCHMS), around August 1971, where CG was again appointed as a Clinical and Research Fellow.

CG surprised Professor Wrong and members of his Unit when he passed the MRCP (London) at his first attempt. Further surprises awaited them, when the External Examiners for the PhD in Dundee recommended awarding him the degree with exemption from the viva voce examination, which is an extremely rare privilege. When CG returned in January 1974, he was the only doctor with both MRCP and a PhD in Sri Lanka. CG was appointed as the Founder Professor and Head, Department of Physiology at the Faculty of Medicine, in the Ruhuna University in 1984, and held that post till 1990, when he was appointed Professor and Head of the Physiology Department at the Faculty of Medicine, University of Colombo.

When I entered the Faculty of Medicine in Colombo in 1982, on our very first day, the first lecture in the Faculty was delivered by CG on the concepts of the body's internal environment, body fluids, and homeostasis. CG was a master at explaining complex systems in a structured and simplified way. His lectures on acid-base balance, for instance, a subject that both undergraduates and postgraduates alike often found perplexing, were models of explanation and exposition. He taught undergraduates of the Faculties of Medicine in Colombo and in Ruhuna for a total period of over 30 years. Over a period of about 15 years he also taught and examined postgraduate doctors of General Surgery, ENT Surgery, Ophthalmic Surgery and Oral-Maxillary Surgery.

CG did not confine his teaching to medical undergraduates and postgraduates. After he was appointed Registrar of the Ceylon Medical College Council (CMCC) in 1999, he implemented the necessary procedures to have well-structured teaching programmes for Pharmacists, and to update and formalise their examinations according to modern concepts of medical education. Under his management the confidential and certification aspects of examinations for all Allied Health Professionals coming within the purview of the CMCC were strengthened and protected from outside interference.

His commitment towards encouraging research and medical writing among the medical community is enormous. Two notable hallmarks of his work that will have a lasting legacy are the Ceylon Medical Journal (CMJ) and the Sri Lanka Clinical Trials Registry (SLCTR). At a time when the CMJ was about to be “derecognised” by the Index Medicus for irregular publication and poor editorial standards, Dr C.G. Uragoda and CG resurrected it by publishing the long overdue volumes in quick succession, by following the International Committee of Medical Journal Editors (ICMJE) specifications, and by proper editing and copy editing. CG’s skills in editing and copy editing are legendary.

By organising regular workshops for doctors on medical writing he was successful in increasing the number, and improving the quality, of articles submitted to the $C M J$. Within a short time, the $C M J$ became a much improved medical journal by local as well as international standards. CG's wit, irrepressible irreverence and editorial experience made $C M J$ Editorial Board meetings, held on the third Saturday of every month, an eagerly awaited event by members. His elegant English style, and passion for clarity and brevity in scientific writing are things I can only envy. I have enjoyed even his rare criticisms as a Member of the Editorial Board.

When ICMJE demands, that were endorsed by the WHO, made national clinical trials registries mandatory for monitoring trials' genuineness, because the giant pharmaceutical manufacturing industry had successfully made a mockery of the basic concepts of clinical trials, CG recognised the urgent need for a Sri Lanka Clinical Trials Registry (SLCTR), and pressed the Sri Lanka Medical Association (SLMA) to spearhead one. Since it was a very new concept, unfamiliar to the Sri Lankan medical fraternity at the time, his request was initially sidelined. However, as usual, he continued to press the issue, and the SLMA finally accepted the need for a SLCTR, and in 2018 CG was invited to be its Founder Chairman. Soon the SLCTR flourished handsomely and became the fourth CTR in the world to be approved by the WHO. The SLCTR is today a Primary Registry of the WHO. Sometimes I wonder how many SLMA's recent leading lights are aware of its own history. How many of us are aware that SLCTR is the only CTR in the world based on a national professional association, thanks to CG's foresight. 
CG is also the senior editor of Sri Lanka Prescriber (SLP) from 1993 - to date. SLP provides expert and independent opinions on clinical pharmacology, and therapeutics and management of disease. When we were medical students the SLP was small in size, tatty and a notably irregular publication. In 1993 CG made it a regular quarterly journal of A4 size, and ensured its free distribution to all medical doctors in the country. This increased its international recognition and helped SLP to become a member of the International Society of Drug Bulletins. CG is a prolific medical writer and his articles have been published in many leading journals such as the British Medical Journal (including one editorial), Clinical Science and Molecular Biology, Medical History, Journal of Evidence Based Medicine, Indian Journal of Physiology and Pharmacology, and the CMJ. He has authored with co-authors five books: Physiology and Biochemistry in Clinical Medicine, Gastroenetreology Update, Sri Lanka Patients' Formulary and Medicine in the Elderly Volumes 1 and 2.

The jewel on the crown of his publications is A Doctor's Quest for Justice - Professor Priyani Soysa vs Rienzie Arsecularatne, which has become a frequently consulted reference on medical negligence among the legal and medical fraternity of Sri Lanka. It has been written with objectivity, accuracy, and comprehensively, with mastery of legal matters, and fearless criticism. The book is critical of several aspects of the Sri Lankan judiciary and some of its personalities. Publishers were reluctant at first to accept it for publication due to Companies being legally advised regarding possible actions for libel and contempt of court. However, when his book was endorsed by the Chief Justice of Sri Lanka at the time, who wrote a Foreword to it, one publisher agreed to publish it. Subsequently, CG was invited by the Editors of the prestigious law journal, Law College Law Review, to write an article titled “Medical Negligence: Where are we Going?”. It was published in 2005 and encompasses virtually all aspects of medical negligence including matters pertaining to patients, doctors, lawyers and the Sri Lankan judicial system.

The book, Medicine in the Elderly in two volumes with chapters authored by specialists in the appropriate fields was another arduous project. The book was a wake-up call and Geriatric Medicine was accepted as a specialty by the Ministry of Health, and training of postgraduates was commenced by the Postgraduate Institute of Medicine. He also served patients immensely by contributing a weekly one-page article to two national newspapers (Divayina and later Lankadeepa), comprising of replies to patients and their relatives' health-related queries. This has now continued for 25 years without interruption, indeed a rare achievement.

In 1982 he was selected by the Sri Lanka Freedom Party to be the Honorary Consultant Physician to the Party's Presidential candidate, Mr. Hector Kobbekaduwa. In the candidate’s car CG toured the island, attending over 200 election meetings. The SLFP's candidate lost the election. As a result of subsequent developments in the political arena he took up a job as an Associate Professor at the King Khalid University Hospital Medical School, Saudi Arabia. He returned to Sri Lanka in 1984 to accept the post of Professor of Physiology at the University of Ruhuna.

For someone with a devotion to several academic responsibilities that demand sustained intellectual energy and expenditure of a great deal of time, CG has been remarkably versatile. In 1994, CG was appointed as Chairman of the State Pharmaceuticals Corporation (SPC). CG showed his skills as an efficient manager, administrator and a reasonable taskmaster during his tenure. During the eight years as the Chairman SPC, he converted the net loss-making SPC to be a profit-making Corporation. In 1997 a Trade Union of medical doctors carried out a vociferous campaign stating that CG was in conflict of interest regarding the award by the SPC of a tender for Triple Vaccine (DPT). A Presidential Commission exonerated him of all allegations and charges. The vociferous Trade Union however did not come to give evidence, although they had been specially invited by the Commission.

In addition to the above posts CG held many other important posts at various times and served the medical community and the country with honour and dignity. In 1988 he was elected President of the Galle Medical Association. He was elected President of SLMA in 1996. CG was also elected President of Sri Lanka Association for the Advancement of Sciences (SLAAS) in 2003. CG organised highly popular SLAAS Science Day Programmes in schools in many distant places of Sri Lanka over a period of 10 years to promote science education among rural school children. He was a member of the Sri Lanka Medical Council from 2011 to 2016, and became its President from October 2017 to July 2018. CG was nominated for the Constitutional Council of Sri Lanka in 2003 and was appointed as Chancellor of the Open University of Sri Lanka in 2016, for a period of 5 years. 
He has won many National Awards including Prime Minister's award Vishva Prasidini in 1996, President’s National Award VidyaJyothi - the highest National Award for Science in Sri Lanka in 2005, and the President's National Award of Deshamanya in 2016, which is the highest national lifetime award for services to the nation. In all probability, CG is the only Sri Lankan who has won these national awards from three Heads of State.

CG has never showed bias whatsoever on gender, ethnicity or religion issues during his life. He ensured that all groups were represented fairly in the Editorial Board of the CMJ. His report and his recommendations, as Chairman of the team that visited the Internally Displaced Persons' camps in Cheddikulam, at the request of the Health Ministry after the civil war had ended, is a clear message about upholding principles of equity and compassion even at times of powerful ethnic and social calamities.

It is a matter of exquisite pleasure and pride for me to write this account on the life and work of CG - a man who has flown higher than all his contemporaries. I wrote this to set down some thoughts longing for expression in my head and my heart to be offered "To Sir with Love". 